\title{
Mixed Cooked Rice with Purple Sweet Potato is Potential to be The Low Glycemic Index Food and Staple Food Alternative
}

\author{
Evawany Aritonang $^{\# 1}$, Albiner Siagian ${ }^{\# 2}$, Fannisa Izzati* \\ ${ }^{\#}$ Community Nutrition Department, University of Sumatera Utara, Jl Universitas No 21, Medan, 20155, Indonesia \\ E-mail: ${ }^{1}$ evawany@gmail.com, ${ }^{2}$ albiner_sgn@yahoo.com \\ *Alumnus of the Graduate Faculty of Public Health, University of Sumatera Utara, Indonesia \\ E-mail: izzatifannisa@gmail.com
}

\begin{abstract}
Rice is the staple food of more than half the world's population. Mixing rice with other food ingredients to become the staple food is never done; therefore the dependence on rice becomes very high. The source of food that contained carbohydrate is diverse such as potatoes, wheat, bananas, cassava and others. This study aims to determine glycemic index and nutrient composition of rice purple sweet potato. The type of research is an experimental study to create a new staple food by mixing rice with purple sweet potato. The main object of research is rice and purple sweet potato with ratio 1: 1 and a blood sample of the subject. The subjects were six women who analyzed their blood glucose levels at every 15 minutes during the first 1 hour and every 30 minutes during the second hour. The results showed the nutrient composition of rice purple sweet potato among others: the water content $53.7 \%$, ash $0.2 \%, 4.4 \%$ protein, $0.6 \%$ fat, $40.7 \%$ carbohydrates, crude fiber $0.17 \%$, and the energy content is 235 kcal. The glycemic index in rice purple sweet potato with white bread as food reference is 67 which are included in the category of food that has a moderate glycemic index (55-70). The rice purple sweet potato potentially as a staple food with a lower glycemic index than the staple food white rice with glycemic index 89. Further research about the glycemic index of rice purple sweet potato as a mixture with other compositions need to do for the purpose of food diversification.
\end{abstract}

Keywords—rice; purple sweet potato flour; glycemic index

\section{INTRODUCTION}

Prevalence of degenerative diseases such as diabetes mellitus (DM), hypertension, and cardiovascular disease tend to increase. This is due to changes in behavior, lifestyle, diet and activity imbalanced. An unbalanced diet characterized by the emergence of nutrition [1]. Based on that, the intake of food needs to be considered to reduce the risk of degenerative diseases, especially in patients or people at risk of degenerative diseases. According to health surveys in Indonesia in 2013 showed that the prevalence of overweight is $13.5 \%, 15.4 \%$ obesity, diabetes mellitus $2.1 \%$, and is expected in 2030 the prevalence of diabetes mellitus in Indonesia reached 21.3 million people [2].

Management of meal or diet is one way to prevent diabetes or blood sugar control in a diabetes patient. This is done by selecting the number and type of carbohydrate that is appropriate to use the concept of the glycemic index. Glycemic index (GI) of food is affecting the level of blood sugar levels with a range of $0-100$. This index is a measure of how much a person's blood sugar levels rise within two or three hours after eating [3].
The scientific consensus statement which recognized the importance of postprandial glycemia in overall health, and the GI as a valid and reproducible method of classifying carbohydrate foods [4]. According to Miller [5] showed that a study feeding low GI with the medium-term in patients with diabetes showed that foods with a low GI are associated with increased blood sugar.

Increased blood sugar levels quickly will increase the need for insulin. If insulin still could equalize, an increase blood sugar levels in short-term are not a problem. However, if the increase is a long period, insulin no longer able to keep blood sugar at a normal level will give rise to type 2 diabetes [3].

The research found that the risk of CVD decreased with low GL and low GI diets [6]. Some studies in Indonesia examined glycemic index in many tubers or cassava that have many local names. The Cilembu cassava that cooked steamed has glycemic index 58.22 [7] lower than Sukun steamed which has a glycemic index of 89 [8]. Another research such as stating that the tubers Walur has a very low glycemic index that is 16.9, and Porang tubers with 
glycemic index 20.6 and Gayong 20.8 while the glycemic index of Uwi tubers 23.1 and Suweg 68.8 [9].

Based on these studies, it can be concluded that the same food can have different glycemic index caused by plant varieties, ways of processing (milling or heating), and the selection of the reference food (bread or glucose) [5]. Moreover, differences in glycemic index foods can also occur due to differences in methods of testing done.

One type of tubers that utilization is still limited in Indonesia is the sweet potato (Ipomoea batatas L). Utilization of sweet potato is generally consumed as snacks such as boiled potatoes, steamed potatoes, baked potatoes, potato chips and others. Only in some regions in Indonesia such as in Papua and Maluku province used sweet potato as a staple food. We could use sweet potatoes as a staple food by mixed rice and purple sweet potato. The type of purple sweet potato is pasta form [10]. The glycemic index of purple sweet potato is low at 51 so that when it consumed, will not raise the blood sugar levels dramatically. Instead of rice and maize contain high GI, so that it can raise blood sugar quickly [11].

The classification of GI foods were high GI foods (GI $\geq$ 70) which digested, absorbed and metabolized quickly and low GI foods (GI < 55) which digested, absorbed and metabolized slowly. Clinical evidence showed that some carbohydrate could be beneficial depending on their GI and fiber content [12], [13].

Rice is the staple food for Indonesian people. Population growth every year resulting the demand of rice is very high. This can affect to food security, so need to consider about other food sources such as sweet potato to reduce dependence on rice. In another hand, this study recommends preventing an increase in degenerative diseases by modifying rice with other foods to get a lower glycemic index. Mixing rice with sweet potato is expected to affect the glycemic index.

Based on research problems, this study aims to determine glycemic index and nutrient composition of rice purple sweet potato and its potential as food with a low glycemic index and decreasing the dependence on rice.

\section{MATERIALS AND METHODS}

This type of research is experimental research conducted at Research Laboratory, Faculty of Public Health University of Sumatera Utara. The subject of research are 6 female students of the Faculty of Public Health with the criteria of 19-22 years of age, in good health condition, have a normal body mass index (18.5 to $\left.24.9 \mathrm{~kg} / \mathrm{m}^{2}\right)$, had no history of diabetes, not having indigestion, not on medication, do not use illegal drugs and does not drink alcohol and are willing to volunteer. Materials used in this study are white bread, rice, sweet potato, a blood sample. The type of purple sweet potato is flour type and mixed with the rice in the cooking process of rice purple sweet potato with a ratio of 1: 1 .

\section{A. Method of Making Sweet Potato Flour}

Fresh purple sweet potato peeled and washed. Then do the slicing potatoes in thin, washed and dried using an electric oven with a temperature of $70^{\circ} \mathrm{C}$ for 24 hours. Purple sweet potato slices were dried crushed using a blender and sieved to get refined purple sweet potato flour.

\section{B. Measurement of Blood Glucose}

Blood glucose measurement using a glucometer SD Check Gold. Blood samples obtained at the surface of the skin with a small injury using a needle lancet, then the blood in the capillaries subject touched on the tip of the sensor opening test strip that has been mounted on a digital detector (glucometer) so that samples of blood glucose levels legible to read.

\section{Measurement of Glycemic Index}

Measurement procedure of glycemic index refers to Miller [5] with the following stages:

- At night the subject (6 people) fasting for \pm 10 hours (except water) starting at $22.00 \mathrm{pm}$ to $08.00 \mathrm{am}$, and in the morning before $08.00 \mathrm{am}$, all subject must be in place to study.

- Subjects were still fasting, and then blood was taken to measure glucose levels.

- Subjects were given a white bread contains 50 grams of carbohydrates as the reference food.

- The blood samples of the subjects were taken every 15 minutes for the first 1 hour and 30 minutes in the second hour (minutes to $15,30,45,60,90$, and to 120) and measured their blood glucose levels using a glucometer. During the study, subjects were asked not to do heavy activity and smoking.

- One week later, conducted tests of food testing ricepurple sweet potato with the same procedure.

- The data of blood sugar levels (at each sampling time) is plotted on two axes; $\mathrm{X}$-axis for duration and $\mathrm{Y}$-axis for blood glucose

- The glycemic index is determined by comparing the area under the curve between the glycemic index of food measured with the food reference.

\section{Data Analysis}

The results of blood glucose levels subjects at every 15 minutes in 1 hour and every 30 minutes in second hours (minutes to $15,30,45,60,90$, and to 120 ) averaged then shown in the $\mathrm{X}$-axis (time) and the $\mathrm{Y}$-axis (blood glucose levels) using graphs. Thus we get a curve which shows the blood glucose response of food that is given to each subject. The data collected, presented in tables and analyzed descriptively.

\section{RESULTS AND DISCUSSION}

Subjects consisted of six women with good health status. Healthy characterized by having a good nutritional status (have BMI of 18.5 to $24.9 \mathrm{~kg} / \mathrm{m} 2$ ), no history of diabetes, are not currently in treatment, not under the influence of drugs and alcohol.

\section{A. Nutrient Composition of Rice Purple Sweet Potato}

Analysis of water content, ash content, protein, fat, crude fiber and carbohydrates in sweet rice potato with $50 \%$ purple sweet potato flour and $50 \%$ of rice carried on Laboratory of Research and Standardization Industry in Medan. The result of analysis can be seen in Table 1 .

Carbohydrates are the best source of calories. The number of calories of 1 gram carbohydrate is $4 \mathrm{kcal}$. The laboratory analysis of nutrients known that carbohydrate content in rice 
purple sweet potato was $40.7 \%$. Its content is lower than the research done by Murni [14] is $75.7 \%$ and also lower than provision by the Indonesia National Standard (INS) by $70 \%$. It can be caused due to purple sweet potato was taken from different areas because of growing regions affects the nutrient composition, and the cooking process can also affect the carbohydrate composition.

The energy contribution of carbohydrate in rice purple sweet potato is $235 \mathrm{kcal}$. Proteins function as growth substances. In 1 gram of protein consist of $4 \mathrm{kcal}$. Protein content in rice purple sweet potato is $4.4 \%$. This content is lower than the levels set by INS that protein is $9 \%$. Likewise, it contents lower than the other research is 11.16 $\%$ [15]. Another research that analyzes nutrient content in rice that mixed some cassava such as red sweet potato, cassava, orange sweet potato and purple sweet potato showed that energy content around 123-146 kcal. The highest energy is in rice with cassava, and the lowest energy is in red sweet potato, while the protein is around 0.8-1.8 gr. The highest protein is in red sweet potato, and the lowest protein is in orange sweet potato [16].

Therefore, rice purple sweet potato in this study has not been a good source of protein because of the low protein content. In order to meet the protein adequacy, remain to need diversity or addition of other foods while consuming rice purple sweet potato.

Fats provide greater energy than carbohydrates and protein, namely $9 \mathrm{kcal}$ per gram. Fat in purple sweet potato rice is measured using Soxhlet extraction method. The higher fat in food makes the food taste more savory and delicious.
Analysis of the fat content of rice purple sweet potato is $0.57 \%$, lower compared to the research is $0.86 \%$ [15].

The water content of the rice purple sweet potato that is $53.7 \%$, higher than the research done by Murni [14] is $7.10 \%$. The difference in moisture content in rice purple sweet potato can be caused due to the difference in the cooking process rice purple sweet potato conducted by researchers.

Ash is a mineral element as the residue left after the material is burned to carbon-free. In the process of combustion, burning of organic material but not inorganic substances, therefore, called ash. Based on the results of the analysis show that the ash content in rice purple sweet potato by $0.2 \%$ lower than Murni research [14] that is equal to $2.55 \%$. Ash content contained in foodstuffs indicates the mineral content amount. The greater the ash content of food indicates the higher mineral in the food material. Fibers in rice purple sweet potato were $0.17 \%$ lower compared to the research conducted by Murni [14] is $2.6 \%$. This concludes that purple sweet potato does not increase fiber content in rice purple sweet potato.

Replacing refined starches (e.g. grains and potatoes) with whole grains was important to approach to reduce the risk of T2DM and CVD because it contains higher amounts of fiber, minerals, and vitamins. Preference test of rice that mixed with various types of potatoes shows that people prefer rice that mixed with purple sweet potato instead of rice mixed with cassava or sweet potatoes in red and orange sweet potato [16].

TABLE I

The Content of Water, Ash, Protein, Fat, Fiber and Carbohydrates In 100 G Rice Purple Sweet Potato

\begin{tabular}{|c|l|c|}
\hline No & \multicolumn{1}{|c|}{ Nutrient } & Amount (\%) \\
\hline 1 & Water & $53.7 \%$ \\
\hline 2 & Ash & $0.20 \%$ \\
\hline 3 & Protein & $4.40 \%$ \\
\hline 4 & Fat & $0.60 \%$ \\
\hline 5 & Carbohydrate & $40.7 \%$ \\
\hline 6 & Crude fiber & $0.17 \%$ \\
\hline
\end{tabular}

\section{B. Blood Glucose Response ( $\mathrm{mg} / \mathrm{dL})$}

Blood glucose measurement using a glucometer named SD Check Gold that obtained blood glucose response of respondents to the provision of a reference food that is white bread. The blood glucose response with white bread as a food reference can be seen in Table 2 .
Giving white bread could raises the blood glucose levels in zero minutes (t.0 ') is $80.1 \mathrm{mg} / \mathrm{dL}$ to $115 \mathrm{mg} / \mathrm{dL}$ at minute 60 (t.60'). Thus after 45 minutes, blood glucose will be increased by $37.2 \mathrm{mg} / \mathrm{dL}$ or $46.44 \%$. The response of blood glucose in blood sample subject to the administration of the test food is rice purple sweet potato can be seen in Table 3 .

TABLE II

BLOOD GLUCOSE RESPONSE WITH WHITE BREAD

\begin{tabular}{|c|c|c|c|c|c|c|c|}
\hline \multirow{2}{*}{ Subject } & \multicolumn{7}{|c|}{$\begin{array}{c}\text { Blood Glucose Response to Food Reference } \\
\text { (White Bread) in Time (Minutes) }\end{array}$} \\
\cline { 2 - 8 } & $\mathbf{0}$ & $\mathbf{1 5}$ & $\mathbf{3 0}$ & $\mathbf{4 5}$ & $\mathbf{6 0}$ & $\mathbf{9 0}$ & $\mathbf{1 2 0}$ \\
\hline 1 & 87 & 79 & 113 & 116 & 115 & 110 & 79 \\
\hline 2 & 79 & 82 & 105 & 113 & 111 & 72 & 77 \\
\hline 3 & 75 & 73 & 95 & 112 & 119 & 96 & 81 \\
\hline 4 & 82 & 89 & 136 & 124 & 123 & 94 & 80 \\
\hline 5 & 78 & 80 & 73 & 117 & 119 & 105 & 80 \\
\hline 6 & 80 & 74 & 82 & 108 & 117 & 101 & 76 \\
\hline Average & 80.1 & 79.5 & 100.6 & 115 & 117.3 & 96.3 & 78.8 \\
\hline
\end{tabular}


TABLE III

Blood Glucose Response with Rice Purple SweEt Potato

\begin{tabular}{|c|c|c|c|c|c|c|c|}
\hline \multirow{3}{*}{ Subject } & \multicolumn{7}{|c|}{$\begin{array}{c}\text { Blood Glucose Response to Test Food } \\
\text { (Rice Purple Sweet Potato) in Time (Minutes) }\end{array}$} \\
\cline { 2 - 8 } & $\mathbf{0}$ & $\mathbf{1 5}$ & $\mathbf{3 0}$ & $\mathbf{4 5}$ & $\mathbf{6 0}$ & $\mathbf{9 0}$ & $\mathbf{1 2 0}$ \\
\hline 1 & 86 & 97 & 112 & 93 & 103 & 93 & 104 \\
\hline 2 & 88 & 89 & 113 & 153 & 160 & 100 & 74 \\
\hline 3 & 82 & 91 & 148 & 143 & 148 & 133 & 104 \\
\hline 4 & 90 & 98 & 120 & 131 & 112 & 107 & 88 \\
\hline 5 & 82 & 93 & 103 & 104 & 112 & 85 & 90 \\
\hline 6 & 90 & 95 & 118 & 130 & 128 & 100 & 89 \\
\hline Average & 86.3 & 93.8 & 119 & 125.6 & 127.1 & 103 & 91.5 \\
\hline
\end{tabular}

Rice purple sweet potato raising blood glucose levels in zero minutes (t.0 ') is $86.3 \mathrm{mg} / \mathrm{dL}$ to $127.1 \mathrm{mg} / \mathrm{dL}$ at minute 60 (t.60'). It can be concluded that in 60 minutes the blood glucose rises $40.8 \mathrm{mg} / \mathrm{dL}$ or $47.27 \%$. Blood glucose response (glycemic index) in rice purple sweet potato will peak rise in minute 60 . This indicates that the test food rice purple sweet potato slow in raising blood glucose levels. Data from the measurement of blood glucose in the subject on reference food and test food dispersed in the curve. The X-axis indicated the time of taking blood and $\mathrm{Y}$ axis indicated blood glucose levels. Thus, the result is a curve that shows the blood glucose response depends on food that is given. The curve can be seen in the Fig. 1 .

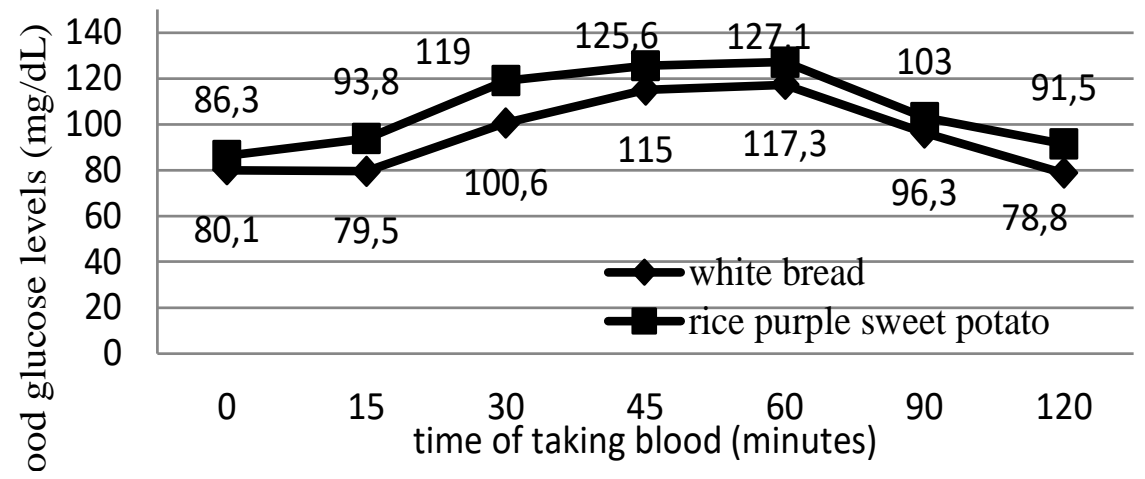

Fig. 1 Curve blood glucose response for white bread and rice purple sweet potato

The glycemic index is calculated by comparing the intervals curve on test food with interval curve on reference food. The glycemic index of a test food obtained from the average value of the glycemic index of six subjects. Subinterval of white bread was divided into 15 sub-intervals.
Each sub-interval is used as rectangular P1, P2, P3, P4, P5, P6, P7, P8, P9, P10, P11, P12, P13, P14, and P15. Based on the calculation of the curve on white bread interval above, the calculation results obtained for 15 subintervals (rectangular building) can be seen in Table 4 .

TABLE IV

CALCULATION OF INTERVAL BREAD CONSUMED

\begin{tabular}{|c|c|c|c|}
\hline \multirow{2}{*}{ Area } & \multicolumn{2}{|c|}{ Side } & \multirow{2}{*}{$\begin{array}{l}\text { Length multiplied by } \\
\text { width }\end{array}$} \\
\hline & Length & Width & \\
\hline $\mathrm{P}_{1}$ & 8 & 6 & 48 \\
\hline $\mathrm{P}_{2}$ & 20 & 8 & 160 \\
\hline $\mathrm{P}_{3}$ & 30 & 9 & 270 \\
\hline $\mathrm{P}_{4}$ & 37 & 8 & 296 \\
\hline $\mathrm{P}_{5}$ & 40 & 6 & 240 \\
\hline $\mathrm{P}_{6}$ & 40 & 4 & 160 \\
\hline $\mathrm{P}_{7}$ & 40 & 3 & 120 \\
\hline $\mathrm{P}_{8}$ & 40 & 3 & 120 \\
\hline $\mathrm{P}_{9}$ & 38 & 11 & 418 \\
\hline $\mathrm{P}_{10}$ & 37 & 7 & 370 \\
\hline $\mathrm{P}_{11}$ & 32 & 7 & 224 \\
\hline $\mathrm{P}_{12}$ & 27 & 7 & 189 \\
\hline $\mathrm{P}_{13}$ & 21 & 7 & 147 \\
\hline $\mathrm{P}_{14}$ & 15 & 7 & 105 \\
\hline $\mathrm{P}_{15}$ & 8 & 4 & 32 \\
\hline \multicolumn{3}{|c|}{ Total Area } & 2899 \\
\hline
\end{tabular}


Based on the calculation of the curve interval of white bread as in Table 4, known that area of white bread which has 15 subintervals of 2899. Calculation interval of white bread is done by calculating the area of a rectangle is the length multiplied width $(\mathrm{L} \times \mathrm{W})$. The total area of the interval white bread used in the calculation formula of glycemic index.
The sub-intervals of rice purple sweet potato were divided into 12 subintervals. Each of these subintervals used rectangular P1, P2, P3, P4, P5, P6, P7, P8, P9, P10, P11, and $\mathrm{P} 12$. Based on the calculation of the curve of rice purple sweet potato interval, the calculation was obtained for 12 subintervals (rectangular) can be seen in Table 5.

TABLE V

Calculation of Interval Rice Purple SweEt Potato Consumed

\begin{tabular}{|c|c|c|c|}
\hline \multirow{2}{*}{ Area } & Length & $\begin{array}{c}\text { Length multiplied by } \\
\text { width }\end{array}$ \\
\cline { 2 - 4 } & 7 & 5 & 35 \\
\hline $\mathrm{P}_{1}$ & 17 & 5 & 85 \\
\hline $\mathrm{P}_{2}$ & 24 & 7 & 168 \\
\hline $\mathrm{P}_{3}$ & 29 & 12 & 348 \\
\hline $\mathrm{P}_{4}$ & 33 & 10 & 330 \\
\hline $\mathrm{P}_{5}$ & 34 & 6 & 204 \\
\hline $\mathrm{P}_{6}$ & 29 & 9 & 261 \\
\hline $\mathrm{P}_{7}$ & 22 & 9 & 198 \\
\hline $\mathrm{P}_{8}$ & 15 & 9 & 135 \\
\hline $\mathrm{P}_{9}$ & 11 & 8 & 88 \\
\hline $\mathrm{P}_{10}$ & 12 & 6 & 72 \\
\hline $\mathrm{P}_{11}$ & 13 & 2 & 26 \\
\hline $\mathrm{P}_{12}$ & Total Area & & 1950 \\
\hline
\end{tabular}

Based on the calculation in the interval of rice purple sweet potato consumed as in Table 5 showed that the area of rice purple sweet potato that has 12 subintervals is equal to 1.950. Calculation interval of rice purple sweet potato is done by calculating the area of a rectangle is the length multiplied width ( $\mathrm{L} \mathrm{x} \mathrm{W)}$.

\section{Glycemic Index}

The glycemic index is calculated by comparing the area curve of test food and area curve of reference food. The value of glycemic index test food obtained from the average value of the glycemic index of six subjects. The value of the test food glycemic index is calculated based on the formula:

$$
\text { Glycemic Index }=\frac{\text { LAUC Rice P Sweet Potate }}{\text { IAUC White Bread }} \times 100 \%
$$

Results of glycemic index rice purple sweet potato can be seen in Table 6.

TABLE VI

GLYCEMIC INDEX (GI) OF FOOD TEST

\begin{tabular}{|c|c|c|c|}
\hline Food Test & $\begin{array}{c}\text { Total Area under } \\
\text { the curve }\end{array}$ & GI & Category \\
\hline $\begin{array}{c}\text { Rice Purple } \\
\text { Sweet Potato }\end{array}$ & 1950 & 67 & Moderate \\
\hline
\end{tabular}

Based on the calculations, the value of glycemic index rice purple sweet potato that is equal to 67 . Based on the results in Table 6 is known that the glycemic index rice purple sweet potato is 67 .

According to Jenny Miller [5], the glycemic index categorized into three groups: low GI with a range of values IG $<55$, moderate GI (intermediate) with values 55-70 IG and high GI with value $>70$. Based on the categorization can be seen that rice purple sweet potato belongs to the group of food that has a moderate glycemic index (55-70).
The glycemic index of rice purple sweet potato is higher than the glycemic index in brown rice in Larasati [17] is 59. This is presumably because, in the manufacture of rice purple sweet potato, milling is done on the purple sweet potato to produce purple sweet potato flour as materials for rice purple sweet potato. Purple sweet potato flour has a particle size smaller than the purple sweet potato intact so that a low fiber content. Low fiber content has a higher glycemic index than high fiber content.

Food that has a low GI are digested and converted into glucose gradually so that the peak blood glucose levels will also be low. In order to control blood glucose levels are encouraged to eat foods that have a low GI but still consider a number of carbohydrates consumed. Plasma glucose, insulin, and ghrelin responses were least favorable when patients with type 2 diabetes consumed a breakfast with a high GI and low fiber, which suggests that reducing the GI or increasing the fiber content could be a useful strategy to maintain the postprandial metabolic profile of diabetes patients [18]. A systematic review and meta-analysis about effects comparison between low glycemic index diets and high glycemic index diets on $\mathrm{HbA} 1 \mathrm{c}$ and fructosamine for diabetes patients showed that there were significant differences of overall effects on HbA1c and fructosamine between low-GI foods group and high-GI foods group in diabetes patient [19].

Factors that can affect the glycemic index of food namely are: 1) the way of processing (starch gelatinization level and particle size), 2) the ratio of amylose to amylopectin, 3) acidity and osmotic level, 4) fiber content, 5) fat content and protein, 6) anti-nutritional content of food [5]. Processing methods affect the value of the glycemic index of food material. This is same with research conducted by Rakhmawati [8] where processing before cooking rice in the rice Ciherang varieties lowers the glycemic index of the rice value becomes 44.2 . 
The particle size also affects the gelatinization process of starch. Pulverization and milling of grains reduce the size of the particles and easier to absorb water. During cooking, water, and heat increase the size of granules. Granules which expands and free starch molecules is very easy to digest. It could be increased in blood sugar levels [5].

The glycemic index of food is also influenced by the composition of nutrients such as fiber, fat, and protein content. Fiber content, especially content of soluble dietary fiber affects the value of GI. According to Chandalia research in Sundari [9], increased consumption of dietary fiber, particularly soluble dietary fiber can lower plasma cholesterol, and improve glycemic control. The analysis of crude fiber content in rice purple sweet potato was $0.17 \%$. Fiber is a physical barrier in the digestive process. This will lead to a slow rate of food in the digestive tract and inhibit the movement of the enzyme. Thus, the process of digestion becomes slow, so that lower blood glucose response [5].

Food that has low GI is essential to prevent degenerative diseases. This is proven by clinical research shown that diets with low GI can improve the control of glycemic and serum lipid among diabetes people and promote the loss of weight. Low GI diets associated with decreased diabetes risk, CHD, and cancer [20]. Fiber consumption provides benefits in controlling blood glucose. Fiber also has a hypoglycemic effect of being able to slow down gastric emptying, glucose diffusion, and glucose absorption, so it could reduce the increase in blood glucose levels.

The study about effect meals with a varying glycemic index on blood glucose response in type 2 diabetes mellitus concluded that plasma glucose shows a positive response to high GI foods and may aggravate the hyperglycemia already present in type 2 DM [21]. In Italian food, from the 141 commercial foods, there were 13 food categories with the composition of $80 \%$ carbohydrate that usually consumed such as fermented milk, juice, soft drink, biscuit, bread, sugar and sweetener, pizza, etc. [22]. Reducing carbohydrate by increasing calories from protein and fat also increased glomerulus filtrate rate (GFR). Future study on GI should examine the long-term effect of this increase in GFR on kidney failure patients [23]. Another study about GI demonstrated that glycemic index of potatoes varies depending on their method of preparation. To minimize GI are advised to precook potatoes and consume them cold or reheat [24]. On the other hand, there is substantial variability in individual responses to GI value that is unlikely to be a guidance in selecting food [25].

Results of the analysis of protein in rice purple sweet potato showed that protein content in rice purple sweet potato is $4.4 \%$. The protein content in rice purple sweet potato is still relatively low when compared with the provisions of Indonesia Standard of food is at least $9 \%$.

Analysis of fat content in rice purple sweet potato is 0.6 $\%$. Fat plays a role in the rate of gastric emptying. Research of Wolever and Bolognesi in Septiyani [26], showed that large amounts of fat ( $50 \mathrm{~g}$ of fat) could lower blood glucose response and insulin response. However, high-fat food of any kind, and even though it has a low GI value, needs to be consumed wisely. A prospective cohort study stated that high dietary GI and GL, primarily due to high intake of refined grains are associated with increased risk of ischemic and hemorrhagic stroke in middle-aged and older urban Chinese women [27].

Consume low GI/low GL meals will decrease hunger, increased satiety, and decreased food intake. Studies reported weight loss after 3 months among obese women who consume low GI foods. Meanwhile, among overweight men fat mass decreased more after 5 weeks consume low GI diets compare with high GI diets [28]. A significant weight loss was achieved after 12 weeks on a diet with a low GIhypocaloric diet for 4 weeks, decreased adipocyte size, a phenotype of adiposity, and decrease body weight and fat mass [29].

\section{CONCLUSIONS}

Nutrient composition of rice purple sweet potato is $53.7 \%$ water, ash $0.2 \%, 4.4 \%$ protein, $0.6 \%$ fat, carbohydrates $40.7 \%$ and $0.17 \%$ crude fiber. Glycemic index of rice purple sweet potato is 67 , and this value is included in the category of food that has a moderate glycemic index value (55-70). The rice purple sweet potato potentially as a staple food alternative with a lower glycemic index than white rice with glycemic index 89 and reduce the dependence on rice.

\section{REFERENCES}

[1] Bustan. "Epidemiology of Non-Communicable Diseases" Jakarta: Rineka Cipta Publisher, 2007

[2] Indonesia Health Ministry. 2013. Indonesia Health Survey

[3] L Liu, X Chu, L Na, F yuan, Y Li, C Sun. "Decreasing high postprandial stearic acid in impaired fasting glucose by dietary regulation". European Journal of Clinical Nutrition vol70, pp.795801,2016

[4] J Kahlhofer, J Karschin, H Silberhorn-Buhler, N Breusing, A Bosy Westphal. "Effect of low glycemic sugar sweetened beverages on glucose metabolism and macronutrient oxidation in healthy men. International Journal of Obesity Jun;40. pp.990-997, 2016

[5] Miller, J. C., Foster-Powell, K., \& Atkinson, F. "The low GI shopper's guide to GI values 2013: the authoritative source of glycemic index values for more than 1.200 foods". Philadelphia: Da Capo Press. 2013

[6] Ma XY, Liu JP, Song ZY. "Glycemic load, glycemic index and risk of cardiovascular diseases: meta-analyses of prospective studies" J Atherosclerosis vol.Aug, pp.223-249, 2012

[7] Maulana, B. 2012 "Effects of Different Treatment against the Glycemic Index (GI) Sweet Potato (Ipomea Batatas) Cilembu" repository.IPB.ac.id

[8] Rakhmawati, FKR, Rimbawan and Leily Amalia. "The Glycemic Index Values Various Products Processed Breadfruit (Artocarpus altilis)" Journal of Nutrition and Food vol.6 (1), pp.28-35, 2011

[9] Sundari, D F. 2014 "Measurement of Glycemic Index Values Cookies Flour Talas Belitung (Xanthosoma sagittifolum)" repository.usu.ac.id

[10] Isa, E. 2014. "Healthy Living with Eating Rice of Rice Colour Dark" https://www.jagita.com

[11] Murtiningsih and Suyanti. " Making Bulbs and Variations processed flour” PT Agro Media Library Jakarta Selatan, 2011

[12] Astrup A, Dyerberg J, Elwood P, Hermansen K, Hu FB, Jakobsen MU. "The role of reducing intakes of saturated fat in the prevention of cardiovascular disease: where does the evidence stand in 2010?" Am J Clin Nutr Apr vol.93, pp.684-688, 2011

[13] Mirrahimi A, de Souza RJ, Chiavaroli L, Sievenpiper JL, Beyene J, Hanley AJ. "Associations of glycemic index and load with coronary heart disease events: a systematic review and metaanalysis of prospective cohorts" J Am Heart Assoc vol.Oct, pp.752, 2012

[14] Murni, M and Moeljaningsih. " Effect of Mixed Type Sweet Potato and Sweet Potato: green beans on the Quality of Rice Sweet Potato Instan" Jurnal News Research Industry vol.118 (3), pp.48-57, 2011

[15] Aritonang. E, Naria E, Rohana A. " Energy and Protein Consumption of Manggadong Rice as Local Wisdom and Effort of Staple Food Diversification" International Journal on Advanced Science, 
Engineering and Information Technology vol.5 no.3, pp.170-173, 2015

[16] Aritonang. E, Naria E, Rohana A. "Public Preferences Of Manggadong Rice as Local Wisdom To Support Food Security In Sumatera Utara Province" Pakistan Journal of Nutrition vol.14 no.5, pp.287-292, 2015

[17] Larasati, S. 2013. "A Nutrient Substance Content Analysis Macro Index and Glycemic Snack Bar Rice Colors For Food Distraction Patients Nefropatidiabetik" eprints. undip.ac.id

[18] Silva FM, Kramer CK, Crispim D, Azevedo MJ. "A high-glycemic index, low-fiber breakfast affects the postprandial plasma glucose, insulin, and ghrelin responses of patients with type 2 diabetes in a randomized clinical trial". J Nutr. 145(4), pp.736-741, 2015

[19] Wang Q, Xia W, Zhao Z, Zhang H. "Effects comparison between low glycemic index diets and high glycemic index diets on HbAlc and fructosamine for patients with diabetes: A systematic review and meta-analysis". Prim Care Diabetes. 9(5), pp.362-369, 2015

[20] Jenkins DJ, Kendall CW, Augustin LS, Mitchell S, Sahye- Pudaruth S, Blanco Mejia S. "Effect of legumes as part of a low glycemic index diet on glycemic control and cardiovascular risk factors in type 2 diabetes mellitus: a randomized controlled trial" J. Arch Intern Med vol.26, pp.1653-1660, 2012

[21] Maulik S, Nayak, Sunil S Patani, Reenu Sharma, Rita Shah. "Effect of meals with varying glycemic index on blood glucose response intype 2 diabetes mellitus". Int J Res Med Sci 4(8) pp.3444-3448, 2016

[22] F.Scazzina, M Dall Asta, M.C Casiraghi, S Sieri, D Del Rio, N Pellegrini, F Brighenti. "Glycemic index and glycemic load of commercial Italian food". Journal of nutrition metabolism cardiovascular disease vol 26 issue5, pp.419-429, 2016
[23] Stephen P Juraschek, Alex R Chang, Lawrence AM Anderson, Deidra C Crew, Letitia Thomas, Jeanne Charleston, Edgar R Miller. "Effect of glycemic index and carbohydrate intake on kidney function in healthy adults". Biomed Central Journal vol17, pp.70, 2016

[24] Arit J Ekpo, Etukudo O Jimmy. "Macronutrient composition and glycemic index of varied prepared meals of irish potatoes in non diabetic subject". American journal of food and nutrition vol4 no 2, pp.51-54, 2016

[25] Nirupa R Matthan, Lynne M Ausman, Huicui Meng, Hocine Tighiouart, Alice H Lichtenstein. "Estimating the reliability of glycemic index values and potential sources of methodological and biological variability" Am J Clin Nutr 104,pp.1004-1013, 2016

[26] Septiyani, I. 2012. "Various Glycemic Index-Based Products Tiwul Cassava (Manihot esculenta Crantz) in Normal People" repository.IPB.ac.id

[27] Yu D, Zhang X, Shu XO, Cai H, Li H, Ding D, Hong Z, Xiang YB Gao YT, Zheng W, Yang G. "Dietary glycemic index, glycemic load, and refined carbohydrates are associated with risk of stroke: a prospective cohort study in urban Chinese women”. Am J Clin Nutr 104(5), pp.1345-1351, 2016

[28] Gopinath B, Flood VM, Rochtchina E, Baur LA, Louie JC, Smith W "Carbohydrate nutrition and development of adiposity during adolescence" J. Obesity (Silver Spring) vol.21, pp.1884-1890, 2013

[29] Rizkalla SW, Prifti E, Cotillard A, Pelloux V, Rouault C, Allouche R."Differential effects of macronutrient content in 2 energy restricted diets on cardiovascular risk factors and adipose tissue cell size in moderately obese individuals: a randomized controlled trial" Am J Clin Nutr vol.95, pp.49-63, 2012 